Ajaps, S. O. \& Obiagu, A. N. (2021). Increasing Civic Engagement Through Civic Education: A Critical Consciousness Theory Perspective

\title{
Increasing Civic Engagement Through Civic Education: A Critical Consciousness Theory Perspective
}

\author{
Sandra Ogechi Ajaps* \\ New York University \\ Adaobiagu Nnemdi Obiagu \\ University of Nigeria \\ *Corresponding Author: soa228@nyu.edu \\ Received : 2019-09-04 \\ Rev. Req. : 2019-10-21 \\ Accepted : 2019-11-22
}

How to cite this paper: Ajaps, S. O. \& Obiagu, A. N. (2021). Increasing Civic Engagement Through Civic Education: A Critical Consciousness Theory Perspective. Journal of Culture and Values in Education, 4(1), 64-87. https://doi.org/10.46303/jcve.2020.2

This is an Open Access article distributed under the terms of the Creative Commons Attribution 4.0 International license (https://creativecommons.org/licenses/by/4.0/).

\section{Abstract}

There is a growing need for increased civic engagement in developing countries. We argue that civic education has not met this need in Nigeria because it is uncritical, but it can be reformed through critical consciousness theory emphasizing knowledge and critical thinking. However, for civic education reforms, we need to understand the relationship between sociodemographic factors and civic engagement. Therefore, we investigated the influence of six sociodemographic factors (gender, location, age, income, education, and ethnicity) on two civic engagement constructs-environmental civility and community volunteering - using the responses of 372 respondents on the Civic Engagement Scale. Results revealed that community volunteerism is mainly influenced by age, gender, and location, while environmental civility is mainly influenced by location and education, and there is a generally low level of civic engagement. The implications of these findings for a critical civic education aimed at increasing critical consciousness and civic action are discussed.

Keywords: Civic engagement, Civic Education, Critical Consciousness

\section{Introduction}

"There is mounting evidence that volunteer engagement promotes the civic values and social cohesion which mitigate violent conflict at all stages and that it even fosters reconciliation in post-conflict situations." - Leigh et al., United Nations Volunteers report, 2011 
Ajaps, S. O. \& Obiagu, A. N. (2021). Increasing Civic Engagement Through Civic Education: A Critical Consciousness Theory Perspective

The evidence on the benefits of volunteering is increasing, as highlighted in the United Nations Volunteers (UNV) report quoted above. Community volunteering is one of the civic engagement activities considered in this study, along with environmental civility. Volunteerism is the practice of performing some tasks, especially social and health tasks, with the motive of helping or fostering development without planned (or expectation of material) rewards for oneself. Volunteering can take the form of social and health services, environmental maintenance, education and religious services, culture and recreation, etc. The altruistic reason of simply helping others has been emphasized as a key motivating factor for volunteering (Jack et al., 2011). However, extrinsic motivations (e.g., praise, résumé enhancement, and money) could also influence volunteerism (see Beehr et al., 2010). People can volunteer toward conserving the environment and preventing ecocide and other disasters; these are attributes of environmental civility.

Environmental civility is an act of obeying environmental laws, policies, and guidelines, together with carrying out environmental civic duties such as environmental sanitation, waste management, etc., either for aesthetic, ecological, ethical, or emotional reasons. Generally, it is positive behavior toward the environment. In this study, environmental civility specifically refers to the environmental sanitation behavior of participants. In line with the opening quote, we argue that the rapidly increasing rate of conflicts and carnage in Nigeria necessitates the promotion of civic values and engagement, which have been found to be poor. For example, environmental attitudes and sanitation practices have been consistently found to be poor (see, e.g., Ekong, 2015; Ogunbode, 2013) and community volunteering is not popular.

However, civic engagement activities have been associated with sociodemographic factors such as age, education, gender, and income (Jennings \& Stoker, 2004; Tindall, Davies, \& Mauboulès, 2003) in countries other than Nigeria. Considering the social structures (ethnocentrism, godfatherism, patriarchy, etc.) of Nigeria, we anticipate patterns of engagement to differ from existing literature. Therefore, in this study, we investigated the relationship between civic engagement (community volunteerism and environmental civility) and sociodemographic factors (gender, location, age, income, education, and ethnicity) in Nigeria. Employing a critical consciousness theory perspective, we focused on how sociodemographic factors could inform a critical civic education toward increased civic engagement.

\section{Civic Engagement}

Civic engagement is defined as acting upon a heightened sense of responsibility to one's communities, which involves developing a wide range of activities including developing civic sensitivity, participation in building civil society, and benefitting the commons (Jacoby, 2009); the participation of individuals in civil life and groupings (Putnam, 2000) is useful for peace and national development. These definitions imply engagement through established institutions; 
Ajaps, S. O. \& Obiagu, A. N. (2021). Increasing Civic Engagement Through Civic Education: A Critical Consciousness Theory Perspective

however, recent studies have shown that engagement could also be personalized (Eimhjellen et al., 2018).

There are varied opinions on whether civic engagement is applicable in the African context because of its assumptions of a self-confident citizenry that has already gained some autonomy from state structures. While some see no difficulty in applying the concept to Africa since nonstate actors are considered as civil society, others believe that post-colonial Africa has remnants of colonial governance in which a majority of the people are under the rule of a designated governor or traditional ruler and do not contribute to governance (Paffenholz \& Spurk, 2006). However, since post-colonial societies are hybrids (Bhabha, 2012) comprising a mix of colonial and indigenous cultures with influences from globalization and imperialism, it is more practical to consider a nuanced position where the concept of civil society is adapted to Africa. This is necessary because Africa's civil societies execute similar functions as the civil society in the West. Yet, Nigeria, like many other post-colonial countries, still has so much power invested in state apparatuses that non-state actors are not powerful enough to challenge oppressive administrations.

Therefore, it is important to study civic engagement in Nigeria to understand how individuals are contributing to building a civil society. This is based on the premise of this paper's opening quote, that civic engagement is necessary for peace and national development. Understanding the nature of Nigerians' civic engagement will also provide knowledge for its improvement through civic education and other avenues. Specifically, what are the socio-demographic characteristics of the people who are more engaged in civic activities? What patterns can we identify? How might these patterns inform the curriculum content and delivery of civic education so that more action is generated from students? What strategies can be employed to reach the groups of people least engaged in civic duties? Before addressing these questions, we describe the Nigerian context, civic education in Nigeria, and the critical consciousness theory that is the specific viewpoint on which this study is framed.

\section{The Nigerian Context}

Nigeria, a West African country, comprises three major ethnic groups (Hausa, Igbo, and Yoruba) and over 250 others. Thus, civic engagement may operate differently in such a context, necessitating this study's investigation of civic engagement with respect to socio-demographic factors (including location and ethnic group). Beyond specific group considerations, the lack of infrastructural facilities like electricity, resulting in crude performance of works and house chores with its antecedents-waste of time and energy-could affect people's commitment to civic engagement in Nigeria compared to the Western world. Also prevalent in Nigeria are gender roles: It is common to find women "behind the scenes" and at home with the kids while men are out working and representing families in communal gatherings. Therefore, this study is significant because applying Western notions of volunteering and environmental civility in Nigeria might suggest low levels of engagement due to incompatible measuring scales. For example, environmental beliefs, consumer behaviors, and global warming perceptions are 
Ajaps, S. O. \& Obiagu, A. N. (2021). Increasing Civic Engagement Through Civic Education: A Critical Consciousness Theory Perspective

conventional measures for environmental civility, whereas measuring public environmental behavior, such as sanitation exercises, is a more suitable measure for Nigeria since waste management is an issue of serious concern in Nigeria. Next, we discuss civic education in Nigeria since the subject is central to civic engagement discourses.

\section{Civic Education in Nigeria}

Civic education is now emphasized in Nigerian primary and secondary schools, with the basic goal of appreciating diversity and governance, promoting national unity and consciousness, and imbibing democratic values through civic engagement. Some contents of civic education such as "respect and maintenance of public places and utilities" (NERDC, 2012) convey environmental civility and community volunteering goals. However, Nigeria's education is still heavily influenced by the colonial education system left behind after the country gained independence from Britain in 1960 (Hardman et al., 2008). This system lacks critique of established knowledge and critique of governing and other social systems, as well as actions that could have developed from such critical thinking since it was designed to create an obedient and productive workforce-what Westheimer and Kahne (2004) dubbed "personally responsible citizens." Despite reform efforts in Nigeria, the basic structure of colonial education remains, and Nigerian civic education remains largely liberal and assimilationist in nature (Obiagu, 2019). Worth noting is that indigenous education, which was eroded by colonial education, promoted indigenous ways of governance, protecting the environment and protecting each other as a community. Thus, Nigerians now grapple with foreign concepts and methods of volunteering and environmental civility, which were engaged in differently in precolonial times.

Civic curriculum across countries is structured to achieve certain civic knowledge, civic skills or abilities, and civic attitude (Cox, Jaramillo, \& Reimers, 2005). This study emphasizes a fourth goal outside those identified by Cox et al. (2005): civic action-any individual or group activity done with the intent to advocate on behalf of the public, solve individual or community problems, etc. However, these themes are either missing (especially civic skills) or present but not focused on or implemented (especially civic attitude) in Nigeria's civic curriculum by teachers, thereby resulting in uncritical education. Importantly, there is a nexus between the nature of civic education (critical or uncritical) emphasized and the patterns and level of civic engagement (Westheimer \& Kahne, 2004).

Worth noting is the finding of Rubin (2007) that students have contrasting civic experiences, suggesting the need for educators to employ classroom practices that will take into account the various civic experiences of students that inform their civic identities if educators are to realize meaningful civic education. Hardy et al. (2010) found a positive correlation between identity and civic engagement. The understanding of civic identities of students and that of citizens (i.e., adults) should shape civic educators' classroom practices, especially because "living in a civically responsive neighbourhood appears to meaningfully support students" commitments to civic participation" (Kahne \& Sporte, 2008, p. 738), as parents' political 
Ajaps, S. O. \& Obiagu, A. N. (2021). Increasing Civic Engagement Through Civic Education: A Critical Consciousness Theory Perspective

knowledge and family political discussion (Finkel \& Ernst, 2005; Kahn, David, \& Lee, 2013; McIntosh, Hart, \& Youniss, 2007) and parents' socioeconomic status (Lott, 2006) influence civic engagement among students. Thus, we investigated how sociodemographic factors shape civic engagement in Nigeria with the hope that our findings would provide sociodemographic evidence that could positively impact the practice of civic education in Nigeria, revealing factors that civic educators should pay attention to in order to make civic lessons meaningful to all learners irrespective of their varying backgrounds, needs, and interests. We reason that the nature of civic education (critical or uncritical) emphasized will affect patterns and level of civic engagement at all stages, especially during adulthood. Based on our findings, we suggest how critical civic education might be fostered through critical consciousness for more powerful civic engagement. In what follows, we highlight the guiding theory of the study.

\section{Theoretical Framing: Critical Consciousness Theory}

This study is guided by Paulo Freire's critical consciousness theory. According to Freire (1974, p. 4), critical consciousness is "learning to perceive social, political, and economic contradictions and to take action against the oppressive elements of reality." It is a process that involves critically analyzing socially constructed norms and beliefs and associated institutions (Horton \& Freire, 1990). Freire (1974) posited that ignorance, defined as lack of knowledge and critical thinking skills, is a key tool in the maintenance of oppression. Believing that raising people's critical consciousness of reality could help eliminate oppression, he proposed critical education as a key solution. Critical consciousness leads to action against oppressive systems, and such actions include civic engagement activities like volunteering in health emergencies in communities without adequate health workers, supporting environmental organizations to restore neglected environments and ecosystems such as the Niger Delta region, and protesting or reporting human rights violations.

Being critically conscious means the ability to apply knowledge and critical thinking skills to examine current situations, develop a deeper understanding of reality, and generate and implement solutions to problems. This should be the purpose of education, rather than the "banking model" (Freire, 1996) in which students are regarded as empty vessels to be filled with knowledge. So, civic education should empower students to critically analyze reality and implement solutions to problems through civic engagement activities. However, for civic education reforms, we need to understand the relationship between sociodemographic factors and civic engagement. Findings could offer insights into effective ways of creating a critical civic education aimed at increasing critical consciousness and civic engagement.

\section{Relationship between Civic Engagement and Sociodemographic Factors}

Here, we discuss the literature on the relationship between sociodemographic factors and the two civic engagement activities that we focused on in this study.

\section{Community Volunteerism and Sociodemographic Factors}


Ajaps, S. O. \& Obiagu, A. N. (2021). Increasing Civic Engagement Through Civic Education: A Critical Consciousness Theory Perspective

According to Hackl, Halla, and Pruckner (2007), volunteering contributes significantly to the economy's welfare that would otherwise require paid resources. Some studies have shown the health benefits of volunteering, especially in aged persons (see Morrow-Howell, 2010; Lum \& Lightfoot, 2005). Just as age is revealed to be a significant factor in volunteering (Jennings \& Stoker, 2004), gender is highlighted (Ostrander \& Fisher 1995). While elite women spend more of their resources on philanthropy, social services, and social action causes than elite men do (Ostrander \& Fisher 1995), low-income women spend more of their resources on informal personal support networks such as caring for the elderly and orphans (Roschelle, 1997). Furthermore, in an American study of 223 people, McBride, Sherraden, and Pritzker (2004) found that low income earners were more heavily involved in church-based volunteering than community volunteering and philanthropism.

These studies showed a pattern of volunteering as dependent on socio-demographic factors; however, these studies were conducted in civilized countries. To the knowledge of the researchers, no similar studies have been conducted in Nigeria. Thus, considering the multifaceted structural disposition of Nigeria-patriarchy, ethnocentrism, and the fact that rural areas are less considered in the distribution of social infrastructures, as well as the high rate of social problems in Nigeria, including environmental issues, which could be ameliorated through volunteering - it is important to investigate patterns of volunteering common among sociodemographic groups in Nigeria. The understanding of the patterns will be useful for developing educational measures more suited to the country and other developing countries with similar characteristics. Thus, the present study investigated the influence of six sociodemographic variables on community volunteerism in Nigeria.

\section{Environmental Civility and Socio-demographic Factors}

Studies on environmental behaviors (such as environmental activism, consciousness, concern, or sensitivity) are overwhelming (c.f., Ajaps \& McLellan, 2015; Gatersleben, Murtagh, \& Abrahamse, 2012; Hinds \& Sparks, 2008; Kollmus \& Agyeman, 2002; Pinto, Nique, Aňaňa, \& Herter, 2011; Uyeki \& Holland, 2000; Zsóka, Szerényi, Széchy, \& Kocsis, 2013). The overarching interest in environmental behaviors could stem from the belief that the survival of the people, economy, and the society, including institutions, are largely dependent on the survival of nature (earth, biodiversity, and ecosystems). However, even though this study delimits environmental civility to environmental sanitation behavior, other studies' findings of the relationship between environmental civility (broadly defined) and sociodemographic factors are presented below, after which we highlight the gaps covered by our study.

Influence of Gender on Environmental Civility: The findings of most studies are congruent with the proposition that women exhibit more environmentally friendly beliefs and behaviors than men (e.g., Ajaps \& McLellan, 2015; Scannell \& Gifford, 2013). Hunter, Hatch, and Johnson (2004) also found that women are more environmentally friendly in private spheres such as recycling. However, Tindall, 
Ajaps, S. O. \& Obiagu, A. N. (2021). Increasing Civic Engagement Through Civic Education: A Critical Consciousness Theory Perspective

Davies, and Mauboulès (2003) had a discrepant result which found no substantial difference to exist on the environmental behavior of both genders.

Influence of Age on Environmental Civility: Some studies showed age as a significant factor influencing environmental behaviors, with older people showing more positive environmental behavior (see Pinto, Nique, Aňaňa, \& Herter, 2011; Gilg, Barr, \& Ford, 2005).

Influence of Education on Environmental Civility: Research evidence has shown that people with more knowledge or education are more likely to be environmentally concerned and produce more positive environmental behavior (Ajaps \& McLellan, 2015; Chanda, 1999; Zsóka, Szerényi, Széchy, \& Kocsis, 2013). Many studies have argued that education or environmental knowledge is not sufficient for generating positive environmental behaviors (e.g., Kollmuss \& Agyeman, 2002), yet some experimental studies (e.g., Duerden \& Witt, 2010) show that, if implemented strategically, environmental knowledge and education can stimulate positive environmental behaviors.

Influence of Location on Environmental Civility: In a U.K. study, students who were raised in rural areas showed more positive environmental concerns than students raised in urban areas (Hinds \& Sparks, 2008). Similarly, a Canadian study found that people in rural areas were more anthropocentric (protective of the environment for satisfaction of human needs) than their urban counterparts (Huddart-Kennedy, Beckley, McFarlane, \& Nadeau, 2009). In contrast, a Chinese study found that people who live in metropolises were more likely to commit to pro-environmental behaviors than people living in small cities (Chen et al., 2011).

Influence of Income on Environmental Civility: Studies on the influence of income on environmental civility or behaviors are mostly seen on national (e.g., Vicente-Monila, Fernandez-Sainz, \& Izagirre-Olaizola, 2013; Dunlap, Gallup, \& Gallup, 1993) or individual (e.g., Uyeki \& Holland, 2000) levels. In a U.S. study, low-income earners were more environmentally concerned than high-income earners (Uyeki \& Holland, 2000).

Influence of Culture on Environmental Civility: Culture and values are said to influence environmental behaviors (Gatersleben, Murtagh, \& Abrahamse, 2012; Kollmus \& Agyeman, 2002). Uyeki \& Holland (2000) found Afro-Americans to be more environmentally concerned than Euro-Americans.

The reviewed studies are mostly bordered on beliefs (e.g., realism, skepticism, certainty, or absolutism) and reactions that follow the beliefs (e.g., ecocentric, anthropocentric, and pro- or anti- environmental behavior), or arguments regarding environmental problems (e.g., humaninduced or natural climate change), and not on the environmental civility (sanitation) aspect of 
Ajaps, S. O. \& Obiagu, A. N. (2021). Increasing Civic Engagement Through Civic Education: A Critical Consciousness Theory Perspective

civic engagement, creating a gap which this study covered by investigating levels of environmental civility among different groups. Nigeria's social structure, including patriarchy and multi-ethnic groups with cultural differences, informed the investigation of whether the six reviewed sociodemographic factors would produce similar influences on environmental civility in the Nigerian context as they did in other countries. We proposed that women, rural, older people, and more educated persons are likely to be more engaged in community volunteerism and to be environmentally engaged.

\section{Method}

This study's design is descriptive research, specifically employing the survey method. The rationale for this method is that we seek to investigate the relationship between two civic engagement variables and six sociodemographic variables, as reported by a sample drawn from the Nigerian population.

\section{Sample}

The study's sample of 372 people was randomly drawn from post-graduate and undergraduate students of the University of Nigeria and community dwellers from eight different ethnic groups. Participants were grouped into Gender (Male and Female), Location (Urban and Rural), Age (Late adolescents: $18-25$ years; Emerging adults: 26-35 years; and Young adults: 36-50 years; Mage $=32.38, \mathrm{SD}=8.88$ ), Educational Qualification (Group 1: Primary Education; Group 2: Secondary Education; and Group 3: Tertiary Education), Income Level (Group 1: —50k; Group 2: \#50k-99k; Group 3: 100k-149k; and Group 4: $\geq 150 k$ ), ${ }^{1}$ and Ethnic Group (Hausa, Idoma, Igbo, Ijaw, Isoko, Itsekiri, Urhobo, and Yoruba). See Table 1 for the composition of the sample's variables.

Consent was first sought and obtained from the participants through written letter. To ensure enough representation of ethnic groups, age groups, income, and educational background, participants were sourced by approaching different "kporakpos" (town unions) ${ }^{2}$ of different age groups (undergraduate and post-graduate students of regular and sandwich enrollees) at the University of Nigeria, as well as communities in Nsukka Metropolis and rural areas.

\begin{tabular}{llll}
\hline Table 1: Profile of Study Participants $(\mathrm{n}=\mathbf{3 7 2})$ & & \\
\hline \multirow{3}{*}{ Gender } & Male & Frequency & Percentage \\
& Female & 220 & 59.1 \\
Location & Urban & 152 & 40.9 \\
& Location & 242 & 65.1 \\
Age & $18-25$ & 130 & 34.9 \\
& $26-35$ & 100 & 29.9 \\
\multirow{3}{*}{ Education } & $36-50$ & 132 & 35.5 \\
& Primary Education & 140 & 37.6
\end{tabular}


Ajaps, S. O. \& Obiagu, A. N. (2021). Increasing Civic Engagement Through Civic Education: A Critical Consciousness Theory Perspective

\begin{tabular}{|c|c|c|c|}
\hline & Secondary Education & 129 & 34.7 \\
\hline & Tertiary Education & 221 & 59.4 \\
\hline \multirow[t]{4}{*}{ Monthly Income } & Less than $\$ 50,000(<\$ 138.8)^{*}$ & 157 & 42.2 \\
\hline & $\$ 50,000-\$ 99,000(\$ 138.8-\$ 275)^{*}$ & 96 & 25.8 \\
\hline & $\# 100,000-149,000(\$ 277.7-\$ 413.8)^{*}$ & 44 & 11.8 \\
\hline & \#150,000 \& above $(\$ 416.6 \& \text { above })^{*}$ & 75 & 20.2 \\
\hline \multirow[t]{8}{*}{ Ethnic Group } & Hausa & 29 & 7.8 \\
\hline & Idoma & 54 & 14.5 \\
\hline & Igbo & 153 & 41.1 \\
\hline & ljaw & 20 & 5.4 \\
\hline & Isoko & 20 & 5.4 \\
\hline & Itsekiri & 13 & 3.5 \\
\hline & Urhobo & 22 & 5.9 \\
\hline & Yoruba & 61 & 16.4 \\
\hline
\end{tabular}

Note: *The amount expressed in dollars in brackets is the equivalent or value of the amount expressed in Nigeria's currency, Naira.

\section{Measure}

The measurement instrument was the Civic Engagement Scale (CES) developed by the second researcher. The instrument has four subscales: political participation, community volunteerism, environmental civility, and human rights activism. The CES, comprised of 10 items, was rated on a 5 -point scale ( $4=$ very much to $0=$ not at all). This study reports only the results of the responses to the community volunteerism subscale measured with two items (e.g., I volunteer in emergency situations such as flood curtailment, etc.) and the environmental civility subscale containing two items (e.g., I participate in community general environmental sanitation, etc.).

Three experts face validated the instrument together with the consent letter that accompanied it. It was further trial tested on 73 respondents. The reliability test on their responses yielded a Cronbach alpha of .78, and the items loaded from as low as .57 to .79 when subjected to a simple Principal Component Analysis. The instrument was adopted and administered on 386 people, reduced to 372 using a listwise deletion method to eliminate incomplete responses. Participants completed the measure on the spot for an average of 40 minutes. The second researcher and her assistant collected the completed measure.

A rotation principal component analysis conducted on the responses of the 372 participants on the 10 items using Varimax with Kaiser Normalization showed that all 10 items loaded heavily (from .40 to .92) on one or more of the four factors with Eigen values higher than 1 and a cumulative variance percentage of 66.61 of the total variance among the items (see Table 2 for details).

Table 2: Rotated Principal Component Analysis of CE Items Using Varimax with Kaiser Normalization 
Ajaps, S. O. \& Obiagu, A. N. (2021). Increasing Civic Engagement Through Civic Education: A Critical Consciousness Theory Perspective

\begin{tabular}{|c|c|c|c|c|c|}
\hline \multirow[t]{2}{*}{ Items } & & \multicolumn{4}{|c|}{ Factors } \\
\hline & & 1 & 2 & 3 & 4 \\
\hline CES 1 & (Vote in Elections) & .409 & & & \\
\hline CES 2 & (Participating in political campaigns) & .917 & & & \\
\hline CES 3 & (Discussing politics) & .477 & .376 & -.336 & .348 \\
\hline CES 4 & (Protesting electoral malpractices) & .902 & & & \\
\hline CES 5 & $\begin{array}{l}\text { (Volunteering in emergency cases and care of } \\
\text { the needy) }\end{array}$ & & & .357 & .801 \\
\hline CES 6 & $\begin{array}{l}\text { (Volunteering in community development } \\
\text { services) }\end{array}$ & & & .865 & \\
\hline CES 7 & (Engaging in general environmental sanitations) & & .545 & .631 & \\
\hline CES 8 & (Clearing littered public place) & & .725 & & \\
\hline CES 9 & (Protesting Human Rights Violations) & & & & .801 \\
\hline CES 10 & (Reporting Human Rights Violations) & & .718 & & \\
\hline \multicolumn{2}{|c|}{ Eigenvalue } & 2.31 & 2.01 & 1.34 & 1.00 \\
\hline \multicolumn{2}{|c|}{ Percentage of Variance } & 22.57 & 20.12 & 13.37 & 10.07 \\
\hline
\end{tabular}

Note: Factors above .30 are reported; Percentage of Cumulative Variance is 66.17; KaiserMeyer-Olkin Measure of Sampling Adequacy is .62; Bartlett's Test of Sphericity is significant at (Chi-Square = 869.192; df = 45) $p<.001$.

Furthermore, item-total correlation was done on all 10 items and the result showed strong correlations ranging from as low as .28 to .62 (see Table 3 for details). The instrument yielded a Cronbach coefficient alpha of .72 which, according to Cohen, Manion, and Morrison (2011), is an acceptable level of internal consistency. Each civic engagement component is the average of the items measuring it (e.g., environmental civility is the average of the two items measuring it) and the middle of the 5-point scale is defined as possession of a measured construct (see Krosnick \& Presser, 2010). Civic engagement is determined by the average of the 10 items.

Table 3: Frequency Distribution and Corrected Item-Total Correlations for Civic Engagement Scale Items

\begin{tabular}{|c|c|c|c|c|c|c|c|}
\hline Items & Description & VM & M & $\mathrm{L}$ & VL & NAA & $r_{i-t}$ \\
\hline 1 & I vote in elections. & 7.3 & 28.5 & 32.8 & 27.4 & 4.0 & $.287^{* *}$ \\
\hline 2 & $\begin{array}{l}\text { I participate in political campaigns and } \\
\text { rallies. }\end{array}$ & 0.5 & 3.0 & 18.0 & 15.9 & 62.6 & $.340 * *$ \\
\hline 3 & $\begin{array}{l}\text { I discuss politics or political issues on face- } \\
\text { to-face interactions or on social media. }\end{array}$ & 0.3 & 13.4 & 33.1 & 25.3 & 28.0 & $.392 * *$ \\
\hline 4 & $\begin{array}{l}\text { I participate in public protests to disapprove } \\
\text { electoral malpractices. }\end{array}$ & 0.5 & 2.7 & 20.2 & 23.9 & 52.7 & $.350 * *$ \\
\hline 5 & I volunteer in emergency situations such as & 3.5 & 37.9 & 26.6 & 20.7 & 11.3 & $.619 * *$ \\
\hline
\end{tabular}


Ajaps, S. O. \& Obiagu, A. N. (2021). Increasing Civic Engagement Through Civic Education: A Critical Consciousness Theory Perspective

caring for the needy in orphanages or old peoples' homes.

6 I voluntarily contribute in building and/or

$\begin{array}{llllll}1.1 & 9.4 & 24.7 & 44.9 & 19.9 & .572^{* *}\end{array}$ maintaining community facilities such as health centers and schools, boreholes, roads, town halls, village squares, markets, etc.

I participate in community or Statedesignated general environmental sanitations.

8 I pick up dirt in halls, classrooms, or places I share with the public and properly dispose it without first being instructed to do so.

9 I protest human rights violations through social media, public rallies, or petition signing.

10 I report cases of human rights violations like violence against children to the appropriate authorities such as the police.

\section{Note: ${ }^{* * *}=p<.001$.}

\section{Method of Analysis}

Descriptive analysis of the participants' (as categorized) scores on all measured constructs was done; variance analyses using different variance statistics were done to determine if statistical differences exist between or among categorical variables.

\section{Results}

\section{Preliminary Analyses}

Preliminary assumption tests were conducted to forestall violation of normality, homogeneity of variance, and independence principles. T-test and one-way ANOVA were basically used for data analysis. A Kruskal-Wallis statistic was used where data violated both normality and homogeneity tests, whereas Welch's ANOVA was used where data violated only homogeneity of variance assumption in cases of three or more categorical variables (Field, 2013). A Tukey HSD, Games-Howell test, and Dun Bonferroni test were conducted for all significant ANOVA, Welch's ANOVA, and Kruskal-Wallis results, respectively (Field, 2013). Mann-Whitney U was used where data violated only normality test, while the alternative t-test result presented in the SPSS output table was used where only the equality of variance test was violated, in cases of two categorical variables. The descriptive statistics (mean [M] and standard deviation [SD]) scores of all participants on all measured variables are presented in Table 4; the mean and SD scores of each independent variable on the measured variables are presented in Table 5. 
Ajaps, S. O. \& Obiagu, A. N. (2021). Increasing Civic Engagement Through Civic Education: A Critical Consciousness Theory Perspective

\begin{tabular}{llll}
\hline Table 4: Mean and Standard Deviation [SD] of Responses on Measures ( $\mathrm{n}=372)$ \\
\hline Measured Variables & Political Participation [PP] & Mean & SD \\
& & 1.21 & .68 \\
Civic Engagement [CE] & Community Volunteerism [CV] & 1.64 & .79 \\
& Environmental "Civility" [EC] & 1.03 & .68 \\
& Human Rights Protection [HRP] & .45 & .47 \\
& Total [CE] & 1.07 & .41 \\
\hline
\end{tabular}

Table 5: Mean and Standard Deviation [SD] of Responses of Each Independent Variable on Measures $(n=372)$

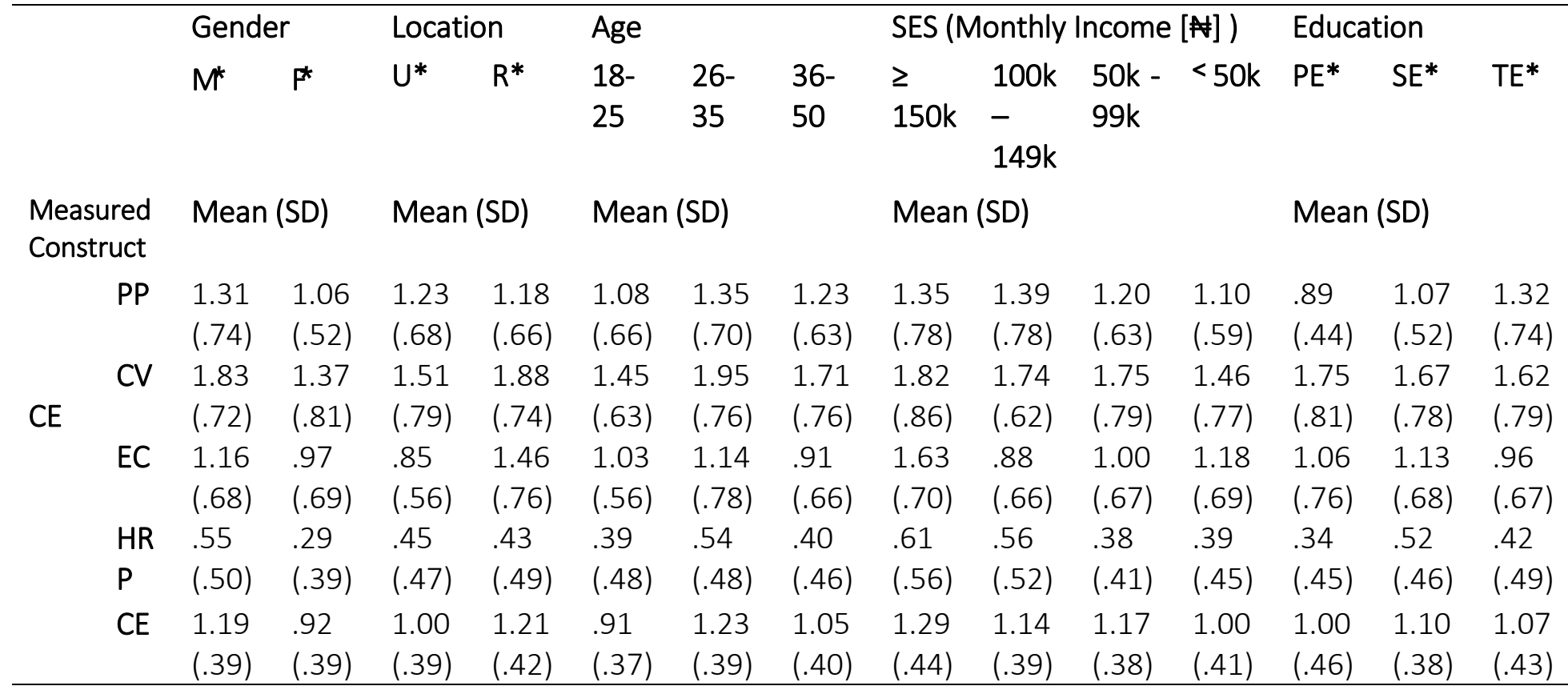

Note: $*$ Naira; $\mathrm{M}=$ Male, $\mathrm{F}=$ Female; $\mathrm{U}=$ Urban, $\mathrm{R}=$ Rural; $\mathrm{H}=$ Hausa, $\mathrm{Id}=\mathrm{Id}$ Idoma, $\mathrm{I}=$ Igbo, $\mathrm{Y}$

$=$ Yoruba, Its = Itsekiri, UR = Urhobo, ISO = Isoko; PE = Primary Education, SE = Secondary

Education, $\mathrm{TE}=$ Tertiary Education .

Table 5 (Cont'd): Mean and Standard Deviation [SD] of Responses of Each Independent Variable on Measures (n $=372$ ) 
Ajaps, S. O. \& Obiagu, A. N. (2021). Increasing Civic Engagement Through Civic Education: A Critical Consciousness Theory Perspective

\begin{tabular}{|c|c|c|c|c|c|c|c|c|c|}
\hline & $\begin{array}{l}\text { Ethnic } \\
\text { Group }\end{array}$ & $H^{*}$ & $I d^{*}$ & $I^{*}$ & ljaw & Iso* & Ist* & Ur* & $\mathrm{Y}^{*}$ \\
\hline \multirow{2}{*}{$\begin{array}{l}\text { Measured } \\
\text { Construct }\end{array}$} & & \multicolumn{8}{|c|}{ Mean (SD) } \\
\hline & PP & $\begin{array}{l}1.18 \\
(.72)\end{array}$ & $\begin{array}{l}1.25 \\
(.68)\end{array}$ & $\begin{array}{l}1.18 \\
(.64)\end{array}$ & $.81(.55)$ & $\begin{array}{l}1.43 \\
(.53)\end{array}$ & $\begin{array}{l}1.03 \\
(.48)\end{array}$ & $\begin{array}{l}1.14 \\
(.64)\end{array}$ & $\begin{array}{l}1.38 \\
(.78)\end{array}$ \\
\hline \multirow[t]{4}{*}{ CE } & $\mathrm{CV}$ & $\begin{array}{l}1.57 \\
(.68)\end{array}$ & $\begin{array}{l}1.87 \\
(.75)\end{array}$ & $\begin{array}{l}1.65 \\
(.75)\end{array}$ & $\begin{array}{l}1.47(1.1 \\
3)\end{array}$ & $\begin{array}{l}1.78(1.0 \\
4)\end{array}$ & $\begin{array}{l}1.77 \\
(.94)\end{array}$ & $\begin{array}{l}1.64 \\
(.56)\end{array}$ & $\begin{array}{l}1.56 \\
(.75)\end{array}$ \\
\hline & EC & $.93(.49)$ & $\begin{array}{l}1.05 \\
(.77)\end{array}$ & $\begin{array}{l}1.08 \\
(.60)\end{array}$ & $\begin{array}{l}1.13 \\
(.65)\end{array}$ & $\begin{array}{l}1.40 \\
(.72)\end{array}$ & $\begin{array}{l}1.57 \\
(.95)\end{array}$ & $.47(.52)$ & $.84(.71)$ \\
\hline & HRP & $.43(.46)$ & $.55(.51)$ & $.43(.47)$ & $.55(.43)$ & $.60(.38)$ & $.69(.48)$ & $.16(.17)$ & $.43(.47)$ \\
\hline & CE & $\begin{array}{l}1.03 \\
(.34)\end{array}$ & $\begin{array}{l}1.27 \\
(.43)\end{array}$ & $\begin{array}{l}1.08 \\
(.38)\end{array}$ & $.97(.46)$ & $\begin{array}{l}1.32 \\
(.37)\end{array}$ & $\begin{array}{l}1.37 \\
(.47)\end{array}$ & $.83(.19)$ & $.99(.48)$ \\
\hline
\end{tabular}

Community Volunteerism [CV]

The results showed a statistically significant difference between the $\mathrm{CV}$ mean scores of male ( $\mathrm{M}$ Rank $=211$ ) and female (M Rank $=149)$ participants $(U=11,158, p<.01)$ and a statistically significant difference between the CV mean scores of rural (M Rank =217) and urban (M Rank $=169)$ participants $(U=19,730, p<.01)$. There is also a significant difference in the mean scores of CV of the different age groups $\left(F(2,369)=36.01, p<.001, \eta^{2}=.63\right)$. Tukey post hoc comparison showed that the mean score of participants aged 18-25 ( $M=1.45)$ differed significantly from that of participants aged 26-35 ( $M=1.95)$ and 36-50 $(M=1.71)$, and that the mean score of $\mathrm{G} 2$ significantly differed from $\mathrm{G} 3$. There is no significant difference in the mean scores of $C V$ of the different education groups $(F(2,369)=.371, p=.69)$. One-way ANOVA on data for income variable showed that there was a significant difference in CV between the different income groups $(F(3,368)=5.15, p=.04)$. Tukey post hoc comparison showed that only the mean score of participants in Group $1(M=1.46)$ differed significantly from that of participants in Group $2(\mathrm{M}=1.75)$ and Group $4(\mathrm{M}=1.82)$. The Kruskal-Wallis test on data for the ethnic group variable showed that there was no significant difference in CV between the different ethnic groups $\left(x^{2}(7)=8.43, p=.29\right)$.

\section{Environmental Civility [EC]}

Preliminary analysis showed a mean difference in EC between male $(M=1.16 ; S D=.68)$ and female $(\mathrm{M}=.97, \mathrm{SD}=.69)$ participants. However, the independent-samples t-test on gender variable showed that there is no statistically significant difference between the mean scores of male and female participants ( $(370)=1.40, p=.16$ ). With respect to location, the results showed a statistically significant difference between the EC mean scores of rural (M Rank $=234$ ) and urban (M Rank $=160$ ) participants $(U=22,000, p<.01)$. The Kruskal-Wallis test on data for age variable showed that there was a significant difference in EC mean score between the different age groups $\left(x^{2}(2)=9.27, p=.008\right)$. Dun Bonferroni test post hoc comparison showed 
Ajaps, S. O. \& Obiagu, A. N. (2021). Increasing Civic Engagement Through Civic Education: A Critical Consciousness Theory Perspective

that only the mean score of participants aged 36-50 (M Rank = 165) and those aged 26-35 (M Rank $=204)$ differed significantly $(p=.007)$.

There is significant difference in the EC mean scores of participants in the different education groups $\left(x^{2}(2)=6.04, p=.049\right)$. Dun Bonferroni test post hoc comparison showed that the mean score of participants in Group 2 and Group 3 significantly differed (.042). One-way ANOVA test on data for the income variable showed no significant difference in the EC mean scores of the different income groups $(F(3,368)=1.16, p=.32)$. The Kruskal-Wallis test on data for ethnic group variable showed significant difference in EC mean score across the different ethnic groups $\left(x^{2}(7)=35.45, p<.01\right)$. Dun Bonferroni test post hoc comparison showed that the mean score of Yoruba participants differed from that of Itsekiri participants, while the mean score of Urhobo participants differed from those of Idoma, Igbo, ljaw, Isoko, and Itsekiri participants.

\section{Discussion}

On the whole, the participants in the study reported low environmental civility and community volunteerism, as shown in Table 4. This could be attributed to low knowledge and critical thinking about these civic engagement components, because indigenous education was deemphasized by colonial rulers and the colonial or Western education in its place either ignores these issues or addresses them from a foreign standpoint that is not very relevant to Nigerians. Thus, we argue that increasing people's knowledge about these components by combining Indigenous and Western ideas, guiding them to think critically about causes and solutions, and motivating them to act could result in increased civic engagement. This idea is expanded in the ensuing discussion of each of the civic engagement components.

\section{Socio-demographic Factors and Community Volunteerism}

Age was found to predict and have a large influence on community volunteerism. Late adolescents (18-25) were least involved in community volunteerism, and emerging adults (2635) who are transitioning to full adulthood were most involved in community activities. This finding contradicts the finding of Jennings and Stoker's (2004) longitudinal investigation of a 1965 cohort across ages 18 to 50, which revealed that engagement in civic organizations was lowest during the transition to adulthood and highest in adolescence and midlife. This contradiction may be because of the pressure from modern day employers on volunteer experiences of their intended employees who are mostly in the transition period (i.e., the emerging adults), or it could be because Jennings and Stoker (2004) focused on belonging to civic organizations while the present study looked at participation irrespective of belonging or not belonging to a civic organization since the new wave of volunteering is more individualized (Eimhjellen et al., 2018).

Furthermore, unlike previous studies (e.g., Ostrander \& Fisher, 1995) that found women to volunteer in social services more than men, this study found that more men undertake community volunteerism than women. This finding could be due to the nature of the measure's 
Ajaps, S. O. \& Obiagu, A. N. (2021). Increasing Civic Engagement Through Civic Education: A Critical Consciousness Theory Perspective

items (volunteering in emergency cases such as flooding and disease outbreak, road maintenance, etc.), which are tasks often left to men. Intriguingly, rural participants reported more community volunteering than their urban counterparts. This finding could be associated with the communal nature of rural areas coupled with the fact that rural participants are more likely to have the time to care for non-relatives and to volunteer in emergency and community services since they are usually less engaged in formal job sectors that are mostly non-flexible and time consuming.

\section{Socio-demographic Factors and Environmental Civility}

Even though there was no statistically significant difference between the male and female participants in this study, there was a mean difference that suggests men to be more environmentally engaged than women. This is inconsistent with previous studies (e.g., Hunter, Hatch, \& Johnson, 2004; Scannell \& Gifford, 2013) and is rather difficult to explain. Perhaps this discrepancy with the findings of other studies could be explained by the fact that one of the two items ("participation in general environmental sanitation") that measured environmental civility is mostly done in places outside the home (e.g., parks, roads, streets, village squares, social infrastructures), and women have been found to be more environmentally conscious in private spheres such as the home (see Hunter, Hatch, \& Johnson, 2004).

Another intriguing finding is that location influences environmental civility. Rural participants were more environmentally civilized than urban participants. This result is in consonance with previous research findings that have found rural residents to be more protective of and interactive with the environment (e.g., Hinds \& Sparks, 2008; Huddart-Kennedy, Beckley, McFarlane, \& Nadeau, 2009). These studies suggested the variance between rural and urban residents to be as a result of the closeness of rural residents to nature. The result could also be explained by place attachment (an emotional bond between a person and a place), especially because rural residents in Nigeria usually have ancestral ties to their location, unlike urban dwellers with residences in rural areas that they call home. That is, rural residents are most likely "at home" and so are more likely to preserve their environment than when in someone else's home or land.

In addition, this finding could also be the result of strong customs and the communal nature of rural areas in Nigeria, whose dwellers are most times not privileged to have the services of government-employed sanitation workers but have to engage in environmental sanitation on a communal basis. Therefore, the higher environmental civility of rural participants could be due to their environmental independence, unlike their urban counterparts who are more likely to depend on government sanitation services. Although environmental hygiene is a universal culture and value, it appears more pronounced in rural Nigeria, as non-compliance with environmental customs attracts customary sanctions such as stigmatization, fines, denial of certain rights, etc., especially in Igbo-speaking parts of Nigeria. This finding supports the positions that social and cultural factors as external factors and values as internal factors 
Ajaps, S. O. \& Obiagu, A. N. (2021). Increasing Civic Engagement Through Civic Education: A Critical Consciousness Theory Perspective

influence environmental behaviors (e.g., Gatersleben, Murtagh, \& Abrahamse, 2012; Kollmus \& Agyeman, 2002).

Moreover, the finding is consistent with studies that found education to be a significant factor in determining environmental behavior (e.g., Chanda, 1999; Zsóka, Szerényi, Széchy, \& Kocsis, 2013). But, quite surprisingly, unlike other studies where environmental behavior increased with education, this study's participants from secondary education backgrounds were more environmentally civilized than participants from primary education backgrounds, while participants from tertiary education backgrounds were the least environmentally civilized. This unprecedented finding may be attributed to the fact that most participants from secondary and primary education backgrounds were rural dwellers, who are shown to be more environmentally conscious, while $75 \%$ of participants with tertiary education backgrounds were urban dwellers.

\section{Implications for Civic Education}

Generally, following from Rubin's (2007) and Hardy et al.'s (2010) studies in different countries linking civic identities to civic engagement, the findings of this study suggest the need for civic educators to explore the civic identities of their learners from different contexts such as gender, location, socioeconomic background, and ethnic (cultural) background. This is because civic identities can hinder or encourage community volunteering and environmental protection through means such as environmental sanitation. Civic educators can engage in suggested exploration through initial class discussions and probing prior to delivery of main instruction so as to identify and employ strategies that could hinder negative civic identities and encourage positive civic identities. This will promote meaningful civic education in Nigeria, which could forestall the reported low civic engagement among adults. Adult educators should also bear in mind the disparate backgrounds of adult learners in their implementation of civic education.

Men were found to be more engaged in civic engagement components requiring strength or outdoor work not considered "homely" and therefore unsuitable for women in Africa. Thus, civic educators need to emphasize and encourage female participation in civic activities. To make the emphasis meaningful, the educators have to first identify and hinder thoughts and female students' adaptation to social structures limiting their human rights, including rights of freedom of movement and association. Higher income was also found to strongly correlate with higher civic engagement. Therefore, civic education should spur action in students so that regardless of wealth status, everyone can be involved in civic activities.

Location matters for civic engagement; rural residents were more likely to be engaged in environmental civility and community volunteering. This may be extended to mean that culture or ethnic group is equally important because of Nigeria's geographic segregation, where ethnic groups are usually clustered in particular locations, forming majorities in such locations. For example, this study's site is in an Igbo region, so it is most likely that participants in rural areas are Igbos (an ethnic group) and in their ancestral homes, while the urban residents are a mix of 
Ajaps, S. O. \& Obiagu, A. N. (2021). Increasing Civic Engagement Through Civic Education: A Critical Consciousness Theory Perspective

Igbo and many other ethnic groups that are in the town because of their university studies or jobs, and have their homes (villages) in other parts of the country. So, how can urban residents, who may not have strong attachments to their temporary homes, become more engaged in civic activities? This is a task for civic education. A suggestion would be for civic education to become more critical in exploring the experiences of people in both urban and rural areas and encouraging students to act to make these experiences better. Civic identities of Nigerian urban students (and rural students) hindering or encouraging community volunteering and environmental protection through environmental sanitation (or protection) should be identified by teachers so as to make civic education practical and meaningful to them.

A critical civic education is necessary because with critical consciousness (i.e., knowledge and critical thinking skills) comes more awareness of oppressive systems and vulnerable people who need society's help. People are empowered to step in when the government neglects its duties with respect to volunteering, environmental sanitation, provision and maintenance of social infrastructure, disaster management, etc. As critical consciousness theory posits, ignorance feeds oppression; therefore, civic education has a duty to raise people's knowledge and critical thinking about their society. It is probable that a critical civic education would raise people's critical consciousness and result in sustained civic engagement.

Incentives such as awards (e.g., the most environmental friendly student) should be provided for students who are environmentally civilized. In addition, the infused environmental education content in many school subjects, especially in civic education, should be given conscious attention. Efforts should also be geared toward eliminating the adoption of environmental sanitation as a form of punishment in schools. Adopting environmental sanitation as a form of punishment could make students dislike it: This, to some extent, defeats sustainable development goal 6: clean water and sanitation. Environmental sanitation should not be left for cleaners alone, as is seen in most urban and private schools. A school sanitation day could be fixed and teachers participate so as to lead examples for their students. This will create a democratic atmosphere and forestall the case of older people abandoning sanitation to younger people. Environmental clubs should also be established in schools at all levels with a focus on linking students to nature and engaging them in protection and sustenance of the environment. Furthermore, field trips in civic education and related disciplines should not be limited to sightings in museums, parks, nature, etc., but should be extended to volunteering for community causes such as care of the elderly, needy, the environment, etc.

Moreover, the government and NGOs should provide volunteering opportunities for individuals. Schools and other institutions should also let individuals understand their role in creating opportunities and effecting changes. In addition, government environmental agencies should stop limiting their functions on general environmental sanitation days to restricting movements; they could visit neighborhoods or communities to democratically and respectfully implore and persuade households to participate. Environmental NGOs could also mobilize people to participate in general environmental sanitation. 
Ajaps, S. O. \& Obiagu, A. N. (2021). Increasing Civic Engagement Through Civic Education: A Critical Consciousness Theory Perspective

\section{Toward a Critical Civic Education in Nigeria}

A critical civic education is one that empowers learners to apply knowledge and critical thinking skills to examine current situations, develop a deeper understanding of reality, and generate and implement solutions to problems. Inferences from the patterns observed between civic engagement and socio-demographic factors can inform the improvement of civic education curriculum and delivery, especially if guided by the theory of critical consciousness. To achieve a critical civic education for all groups in Nigeria, students should be involved in actions that include the following:

- Exploring questions related to freedom, authority, social responsibility, and personal purpose in local and global contexts.

- Engaging in conversations about known (e.g., through the media) and unknown (e.g., personal experience) oppressive systems, maltreated people, etc.

- Engaging in self-reflection to develop critical consciousness.

- Telling stories, analyzing news articles, pictures, and videos of oppressed people.

- Sharing motivating stories of people's lives being improved because of raised critical consciousness and civic engagement activities.

- Engaging in diverse civic engagement activities in and out of school environments, individually and in groups.

Additionally, educators should consider the following in their instructional practices:

- Peculiar challenges (e.g., exclusive cultural rules inhibiting the full realization of women's potential) affecting female participation in civic activities.

- Special circumstances affecting community volunteerism and environmental protection skills of urban residents and learners.

Generally, civic education needs to incorporate more indigenous knowledge in order to be relevant to Nigerians and raise their critical consciousness, thereby empowering them to understand and improve their society. Primary and secondary schools' civic education curricula should be structured in such a way as to create participatory opportunities for students. This could be achieved by liaising with Youth Forums and NGOs to create interactive sessions on key societal issues with students.

\section{Limitation of the Study and Suggestion for Further Studies}

Certain limitations may affect this study's generalizability. First, some of the study's participants are both indigenes and residents of the study area while many others are only residents and have their indigenous origins in other parts of the country. Therefore, even though participants were grouped by ethnicity (indigenous origins), there could be some social or culture-contact impact, especially for those who have lived in the study area for longer periods, and this could influence their views and actions. Therefore, a future study in this area should consider a sample that would comprise both indigenes and residents of a particular area to reduce the effect of culture-contact. Furthermore, the civic engagement scale we used in this study is new and the items did not capture all civic activities for each subscale. Even though preliminary 
Ajaps, S. O. \& Obiagu, A. N. (2021). Increasing Civic Engagement Through Civic Education: A Critical Consciousness Theory Perspective

assessments and tests indicate high validity and reliability, further testing and application with other samples should be done to establish the scale's robustness.

\section{Conclusion}

With the urgent need for increased civic engagement in Nigeria, a critical civic education in Nigeria is crucial. Understanding the relationship between civic engagement and sociodemographic factors is also vital for civic education reforms. A critically conscious civic education in Nigeria would consider sociodemographic differences in empowering students to apply knowledge and critical thinking skills to build a civil society through civic engagement. This is important because civic engagement contributes to the reduction of problems like neglected community members (especially the aged and physically challenged), environmental degradation, human rights violations, political apathy, oppression, and inter-ethnic intolerance and violence. However, civic education needs to be culturally respectful of the place and people, and promote activities that spur increased knowledge and critical thinking around local and global issues of volunteering, the environment, and other aspects of civic life. These could empower students to strive for positive changes in their immediate environment, their country, and the world.

\section{Endnotes}

1. Some of the participants have at least one dependent, indicating that income may not have a direct effect.

2. Kporakpo (town union) is a term used to refer to communal or ethnic clubs or unions formed outside the immediate community or ethnic group. 
Ajaps, S. O. \& Obiagu, A. N. (2021). Increasing Civic Engagement Through Civic Education: A Critical Consciousness Theory Perspective

\section{References}

Ajaps, S., \& McLellan, R. (2015). "We don't know enough": Environmental education and proenvironmental behaviour perceptions. Cogent Education, 2, 1-17.

http://dx.doi.org/10.1080/2331186X.2015.1124490

Beehr, T. A., LeGro, K., Porter, K., Bowling, M. A., \& Swader, W. M. (2010). Required volunteers: Community volunteerism among students in college classes. Teaching of Psychology, 37(4), 276-280. DOI: 10.1080/00986283.2010.510965

Bhabha, H. K. (2012). The location of culture. London: Routledge.

Chanda, R. (1999). Correlates and dimensions of environmental quality concern among residents of an African subtropical city: Gaborone, Botswana. Journal of Environmental Education, 30(2), 31-39.

Chen, X., Peterson, M. N., Hull, V., Lu, C., Lee, G. D., Hong, D., \& Liu, J. (2011). Effects of attitudinal and sociodemographic factors on pro-environmental behaviour in urban China. Environmental Conservation, 38(1), 45-52. doi:10.1017/S037689291000086X

Cohen, L., Manion, L., \& Morrison, K. (2011). Research methods in education (11 $1^{\text {th }}$ ed.). London: Routledge.

Cox, C., Jaramillo, R., \& Reimers, F. (2005). Education for democratic citizenship in the Americas: An agenda for action. New York: Inter-American Development Bank. Retrieved from https://www.researchgate.net/publication/254423036

Duerden, M. D., \& Witt, P. A. (2010). The impact of direct and indirect experiences on the development of environmental knowledge, attitudes, and behavior. Journal of Environmental Psychology, 30(4), 379-392.

Dunlap, R. E., Gallup, G. H., \& Gallup, A. M. (1993). 'Of global concern': Results of the health and planet survey. Environment: Science and Policy for Sustainable Development, 35(9), 7-39.

Eimhjellen, I., Steen-Johnsen, K., Folkestad, B., \& Odegard, G. (2018). Changing patterns of volunteering and participation. In B. Enjolras and K. Stromsnes (Eds.), Scandinavian civil society and social transformations, nonprofit and civil society studies (pp. 25-65). Norway: Springer International Publishing AG.

Ekong, I. E. (2015). An assessment of environmental sanitation in an urban community in Southern Nigeria. African Journal of Environmental Science and Technology, 9(7), 592-599. 
Ajaps, S. O. \& Obiagu, A. N. (2021). Increasing Civic Engagement Through Civic Education: A Critical Consciousness Theory Perspective

Field, A. (2013). Discovering statistics using SPSS: (And sex and drugs and rock ' $n$ ' roll) (4 $4^{\text {th }}$ ed.). London: SAGE.

Finkel, S. E., \& Ernst, H. R. (2005). Civic education in post-apartheid South Africa: Alternative paths to the development of political knowledge and democratic values. Political Psychology, 26(3), 333-364.

Freire, P. (1974). Conscientisation. Cross Currents, 24(1), 23-31.

Freire, P. (1996). Pedagogy of the oppressed (revised). New York: Continuum.

Gatersleben, B., Murtagh, N., \& Abrahamse, W. (2014). Values, identity, and pro-environmental behaviour. Contemporary Social Science, 9(4), 374-392. DOI:10.1080/2158204.2012.682086

Gilg, A., Barr, S., \& Ford, N. (2005). Green consumption or sustainable lifestyles? Identifying the sustainable consumer. Futures, 37(6), 481-504. doi:10.1016/j.futures.2004.10.016

Hackl, F., Halla, M., \& Pruckner, G. J. (2007). Volunteering and income - the fallacy of the good Samaritan? KYKLOS, 60(1), 77-104.

Hahn, C. L. (1999). Citizenship education: An empirical study of policy, practices and outcomes. Oxford Review of Education, 25(1-2), 231-250. https://doi.org/10.1080/030549899104233

Hardman, F., Abd-Kadir, J., \& Smith, F. (2008). Pedagogical renewal: Improving the quality of classroom interaction in Nigerian primary schools. International Journal of Educational Development, 28(1), 55-69.

Hardy, S. A., Pratt, M. W., Pancer, S. M., Oslen, J. A., \& Lawford, H. L. (2010). Community and religious involvement as contexts of identity change across late adolescence and emerging adulthood. International Journal of Behavioral Development, 35(2), 125-135.

Hinds, J., \& Sparks, P. (2008). Engaging with the natural environment: The role of affective connection and identity. Journal of Environmental Psychology, 28(2), 109-120. doi:10.1016/j.jenvp.2007.11.001

Horton, M., \& Freire, P. (1990). We make the road by walking: Conversations on education and social change. Temple University Press.

Huddart-Kennedy, E., Beckley, T. M., McFarlane, B. L., \& Nadeau, S. (2009). Rural-urban differences in environmental concern in Canada. Rural Sociology, 74(3), 309-329. doi:10.1526/003601109789037268 
Ajaps, S. O. \& Obiagu, A. N. (2021). Increasing Civic Engagement Through Civic Education: A Critical Consciousness Theory Perspective

Hunter, L. M., Hatch, A., \& Johnson, A. (2004). Cross-national gender variation in environmental behaviors. Social Science Quarterly, 85(3), 677-694.

Jack, B. A., Kirton, J. A., Birakurataki, J., \& Merriman, A. (2011). The personal value of being a palliative care community volunteer worker in Uganda: A qualitative study. Palliative Medicine, 26(5), 753-759. DOI: 10.1177/0269216311413628

Jacoby, B. (2009). Civic engagement in higher education: Concepts and practices. San Francisco, CA: Jossey-Bass.

Jennings, K. M., \& Stoker, L. (2004). Social trust and civic engagement across time and generations. ActaPolitica, 39(4), 342-379. Doi:10.1057/palgrave.ap.5500077

Kahne, J., David, C., \& Lee, N. (2013). Different pedagogy, different politics: High school learning opportunities and youth political engagement. Political Psychology, 34(4), 419-441.

Kahne, J. E., \& Sporte, S. E. (2008). Developing citizens: The impact of civic learning opportunities on students' commitment to civic participation. American Educational Research Journal, 45(3), 738-766. https://doi.org/10.3102/0002831208316951

Kollmuss, A., \& Agyeman, J. (2002). Mind the gap: Why do people act environmentally and what are the barriers to pro-environmental behavior? Environmental Education Research, 8(3), 239260. DOI: $10.1080 / 13504620220145401$

Krosnick, J. A., \& Presser, S. (2010). Question and questionnaire design. In P. V. Marsden \& J. D. Wright (Eds.), Handbook of survey research ( $2^{\text {nd }}$ ed.). Bingley, UK: Emerald Group Publishing.

Leigh, R., Smith, D. H, Lough, B. J, Mati, J. M., Giesing, C., León, M. J., ... Strassburg, S. (2011). State of the world's volunteerism report: Universal values for global wellbeing. Bonn, Germany: United Nations Volunteers (UNV).

Lott, J. L. II. (2006). Racial identity and black students' perceptions of civic skills. Race, Gender \& Class, 13(3/4), 239-254.

Lum, T. Y., \& Lightfoot, E. (2005).The effects of volunteering on the physical and mental health of older people. Research on Aging, 27(1), 31-55. DOI: 10.1177/0164027504271349

McBride, A. M., Sherraden, M. S., \& Pritzker, S. (2004). Civic engagement among low-income and low-wealth families: In their words. Working Paper No. 04-14, Center for Social Development Global Service Institute, George Warren Brown School of Social Work, Washington University. 
Ajaps, S. O. \& Obiagu, A. N. (2021). Increasing Civic Engagement Through Civic Education: A Critical Consciousness Theory Perspective

McIntosh, H., Hart, D., \& Youniss, J. (2007). The influence of family political discussion on youth civic development: Which parents qualities matter? Political Science and Politics, 40(3), 495499. DOI:10.1017/S1049096507070758

Morrow-Howell, N. (2010). Volunteering in later life: Research frontiers. Journal of Gerontology: Social Sciences, 65B(4), 461-469. doi:10.1093/geronb/gbq024

Nigerian Educational Research and Development Council (NERDC). (2012). Federal ministry of education junior secondary education curriculum. Abuja: UBEC.

Obiagu, A. N. (2019). Influence of teacher's characteristics on civic education implementation in Nigeria. Journal of Culture and Values in Education, 2(2), 1-20. Retrieved from https://cultureandvalues.org/index.php/JCV/article/view/32

Ogunbode, C. A. (2013). The NEP scale: Measuring ecological attitudes/worldviews in an African context. Environment, Development and Sustainability, 15(6), 1477-1494. doi:10.1007/s10668013-9446-0

Ostrander, S., \& Fisher, J. (1995). Women giving money, women raising money: What difference for philanthropy? New Directions for Philanthropic Fundraising, 1995(8), 67-78.

Rubin, B. (2007). "There's still not justice": Youth civic identity development amid distinct school and community contexts. Teacher College Record, 109(2), 449-481.

Paffenholz, T., \& Spurk, C. (2006). Civil society, civic engagement, and peacebuilding. Social Development Papers, Paper No 36, 10-55. Conflict Prevention and Reconstruction Social Development Department, World Bank. Retrieved from http://www.worldbank.org/conflict

Pinto, D. C., Nique, W. M., Aňaňa, E. d. S., \& Herter, M. M. (2011). Green consumer values: How do personal values influence environmentally responsible water consumption? International Journal of Consumer Studies, 35(2), 122-131.

Putnam, R. D. (2000). Bowling alone: America's declining social capital. In Culture and politics (pp. 223-234). New York, NY: Palgrave Macmillan.

Roschelle, A. (1997). No more kin: Exploring race, class, and gender in family networks. Thousand Oaks, CA: Sage.

Scannell, L., \& Gifford, R. (2013). Personally relevant climate change: The role of place attachment and local versus global message framing in engagement. Environment and Behavior, 45(1), 60-85. https://doi.org/10.1177/0013916511421196 
Ajaps, S. O. \& Obiagu, A. N. (2021). Increasing Civic Engagement Through Civic Education: A Critical Consciousness Theory Perspective

Tindall, D. B., Davies, S., \& Mauboulès, C. (2003). Activism and conservation behavior in an environmental movement: The contradictory effects of gender. Society and Natural Resources, 16(10), 909-932. DOI: 10.1080/08941920390231478

Uyeki, E. S., \& Holland, L. J. (2000). Diffusion of pro-environment attitudes? American Behavioral Scientist, 43(4), 646-662.

Vicente-Monila, M. A, Fernandez-Sainz, A., \& Izagirre-Olaizola, J. (2013). Environmental knowledge and other variables affecting pro-environmental behaviour: Comparison of university students from emerging and advanced countries. Journal of Cleaner Production, 61, 130-138. doi:10.10.1016/j.jclepro.2013.05.015

Zsóka, A., Szerényi, M. Z., Széchy, A., \& Kocsis, T. (2013). Greening due to environmental education? Environmental knowledge, attitudes, consumer behavior and everyday proenvironmental activities of Hungarian high school and university students. Journal of Cleaner Production, 48, 126-138. DOI:10.1016/j.jclepro.2012.11.030 